\title{
Students' Problems in Writing Paraphrases in Research Paper Writing Class
}

\author{
Herdiansari Hayuningrum \\ Made Frida Yulia \\ Sanata Dharma University
}

\begin{abstract}
Paraphrase is one of the techniques of incorporating sources in which every writer is allowed to borrow the author's ideas and restate them into their own words. Based on the previous study, it was found that English Language Education Study Program (ELESP) students, Sanata Dharma University, were unable to paraphrase properly since they tended to copy the author's words directly. If this problem was continuously ignored, it would be dangerous for the students because they could be charged with inadvertent plagiarism. This study was intended to investigate ELESP students' problems in writing paraphrases and the reasons why they produce unacceptable paraphrases by conducting document analysis and interview in Research Paper Writing class. From the findings, it could be identified that the most frequent type of problem encountered by the students was word-for-word plagiarism.
\end{abstract}

Keywords: paraphrase, inadvertent plagiarism, students' problems

\section{A. INTRODUCTION}

There are two basic ways of incorporating sources in writing. They are quotation and paraphrase (Spatt, 1999; Trzeciak and Mackay, 1998). According to Roth (1986), quotations, as "the words of experts in the field," are important to be used in writing a paper but the students must be careful in using them since they may lose the originality of their own works if their papers are only a series of quotations (p. 6). On the contrary, in writing paraphrases, the students borrow only the ideas of the author and rewrite them into their own words. Although it takes more times, paraphrasing can demonstrate whether they really understand the authors' argument or not. Based on the previous study conducted by Prabandari (1997), it was found that English Language Education Study
Program (ELESP) students, Sanata Dharma University, whether they realized it or not, frequently used paraphrase in their papers (p. 72). However from her analysis, what the students did was not really paraphrasing but merely copying the same words without including the quotation marks. Inability to paraphrase properly would become a crucial problem for ELESP students since it can lead them to the charge of plagiarism. Furthermore, as teacher candidates, they would be a role model for their students. If they could not use sources properly in order to avoid plagiarism, they would not be able to guide their students to use the proper ones. For those reasons, this study would like to address two questions. First, what problems are encountered by ELESP students in writing paraphrases? Second, why do 
ELESP students produce unacceptable paraphrases in their writing?

To answer the first research question, the researchers conducted document analysis. The documents to be analyzed were research papers submitted by ELESP sixth semester students who were taking Research Paper Writing class in the academic year 2010/2011. The data were taken from classes A, B, D, and F students as the representative of four different lecturers of Research Paper Writing. Furthermore, to investigate the students' reasons for producing unacceptable paraphrases, the researchers conducted an interview with eight ELESP students who produced unacceptable paraphrases in their papers.

\section{B. THEORETICAL GROUND}

\section{The Problems with Paraphrasing}

Paraphrasing is absolutely a valuable skill which is necessarily needed for academic writing. Unfortunately, this skill cannot be easily mastered by the students. Many serious problems might come up when the students have not been taught to paraphrase accurately and properly. As mentioned by Gilmore (2008), "The problem with paraphrasing, frankly, is that most students haven't learned to do it well" (p. 28).

\section{a. Eight Paraphrase Pitfalls}

According to Kennedy and Smith (1986), there are some dangers dealing with paraphrasing which are categorized into eight paraphrase pitfalls: misreading the original, including too much of the original, leaving out important information, adding opinion, summarizing rather than paraphrasing, substituting inappropriate synonyms, expanding or narrowing the meaning, and forgetting to document (p. 38)

b. Plagiarism in Paraphrasing
Based on the students' writing guidelines of some high rank universities, like University of Wisconsin and Central Queensland University, there are two types of plagiarism in paraphrasing. They are word-for-word plagiarism and a patchwork paraphrase. The first sort of plagiarism is direct copying which is called as word-for-word copying by Division of Teaching \& Learning Services of Central Queensland University (2007). This plagiarism is easy to detect because the students directly copy the exact words of the original source without giving proper acknowledgement. The second plagiarism is a patchwork paraphrase which contains original language from the author as a result of poor cut-andpaste practice (Division of Teaching \& Learning Services of Central Queensland University, 2007).

\section{The Causes of Problems in Paraphrasing}

According to some related theories, there are several causes of poor paraphrasing.

\section{a. A Low Reading Comprehension}

According to a writing guideline "Referencing and Paraphrasing" by Latrobe University (2010), "Poor paraphrasing is often the result of poor understanding of the text. Some students try to paraphrase at the sentence level rather than the ideas level." McNamara (2007) also finds that there is "a positive correlation between inaccurate paraphrases and poor comprehension of a text" ( $p$. 477).

\section{b. Working in a Second Language}

Furthermore, according to Gibaldi (2003), the students who have to write papers in a second language may face certain difficulties in paraphrasing. As stated by Gibaldi (2003), "In an effort to avoid 
grammatical errors, they may copy the structure of an author's sentences. When replicating grammatical patterns, they sometimes inadvertently plagiarize the author's ideas, information, words and expressions" (p. 70). Besides, Hong Xu (2010) also reveals another problem deals with paraphrasing, for instance the students can produce inaccurate paraphrase which is different from the original meaning or a paraphrase "with a structure reflective of L1 syntactic interference." This problem can occur because the students "translate an original sentence from English to L1, paraphrase it in L1, and then translate the paraphrased sentence from L1 to English" (p. 247).

\section{c. Dealing with Plagiarism Practice}

Equally important, poor paraphrasing is also highly related to plagiarism. Gilmore (2008) argues that poor paraphrasing skill is included in unintentional plagiarism (p. 41). As supported by MIT Academic Integrity (2007), unintentional plagiarism can occur "not because a student is trying to cheat, but because he or she has not been taught how to paraphrase accurately." Afterwards, as remarked by Hubbuch (1992), there are several reasons why unintentional plagiarism happened. They are carelessness in the research process, sloppiness while writing the paper, ignorance of the "giving-credit-where-credit-is-due" rule, and "passive-sponge" approach to research (pp. 163-164). Furthermore, according to Davis and Carrol (2009) as cited in "Addressing Plagiarism" (2011), the students whose mother tongue is not English have particular problems which cause plagiarism, like a lack of vocabulary as a part of their language incompetence.

\section{DISCUSSION}

\section{The Students' Problems in Writing Paraphrases}

To answer the first research question, the data were taken from classes A, B, D, and F. On the submission days, they were 97 papers submitted as the final project. However, in analyzing the data, the researchers only focused on the research papers which contained paraphrases. Based on the research findings, there were 76 students (78.35\%) who used paraphrases. On the contrary, there were only 21 students $(21.65 \%)$ who did not use paraphrases in their papers. The total of the students who used paraphrases showed that paraphrasing was commonly used by the sixth semester students of ELESP in the academic year $2010 / 2011$ as one of the techniques of incorporating sources in writing.

Unfortunately, not all paraphrases were able to be analyzed further. From 76 students who used paraphrases, there were 11 students whose paraphrases could not be checked because of the technical problems in finding and gathering the original sources, such as unclear references, unavailable printed sources, and broken or moved online sources. Therefore, to produce more accurate findings, they were not further included in the process of calculating and analyzing data. After all of the paraphrases were completely analyzed, from the total of students who used paraphrases (excluding those students whose sources were not found), surprisingly it was found that as many as 62 students (95.38\%) produced unacceptable paraphrases. On the contrary, only three students (4.61\%) were able to produce acceptable paraphrases in their papers. The very 
high number of the students who produced unacceptable paraphrases showed that most of ELESP students who were taking Research Paper Writing class in the academic year 2010/2011 had trouble with paraphrasing correctly.

After the analysis of all the problems in students' unacceptable paraphrases was accomplished, the researchers calculated the percentage of the total problems from each type of the problems as shown in Table 1 . The total problems found in the students' research papers were 170 problems. Based on the research findings, it was revealed that the most frequent type of problem encountered by the students was word-for-word plagiarism which occurred 94 times (55.3\%).

Table 1 The Results of Identified Problems in Students' Paraphrases

\begin{tabular}{|c|c|c|c|}
\hline No. & Type of Problem & Frequency & Percentage \\
\hline \multicolumn{4}{|c|}{ Paraphrase Pitfalls } \\
\hline 1. & Forgetting to document & 19 & $11.18 \%$ \\
\hline 2. & Including too much of the original & 17 & $10 \%$ \\
\hline 3. & Misreading the original & 9 & $5.3 \%$ \\
\hline 4. & Leaving out important information & 6 & $3.53 \%$ \\
\hline 5. & Adding opinion & 5 & $2.9 \%$ \\
\hline 6. & $\begin{array}{l}\text { Expanding or narrowing the } \\
\text { meaning }\end{array}$ & 2 & $1.18 \%$ \\
\hline 7. & $\begin{array}{l}\text { Substituting inappropriate } \\
\text { synonyms }\end{array}$ & 1 & $0.58 \%$ \\
\hline 8. & $\begin{array}{l}\text { Summarizing rather than } \\
\text { paraphrasing }\end{array}$ & - & - \\
\hline \multicolumn{4}{|c|}{ Plagiarism in Paraphrasing } \\
\hline 1. & Word-for-word plagiarism & 94 & $55.3 \%$ \\
\hline 2. & A patchwork paraphrase & 17 & $10 \%$ \\
\hline \multicolumn{4}{|c|}{ Total problems } \\
\hline
\end{tabular}

Next, to fully describe the identified problems, several cases of students' unacceptable paraphrases were given.

a. Example of Word-for-word Plagiarism

From 170 problems which existed, 94 problems (55.3\%) belong to word-for-word plagiarism. One of the cases of word-for-word plagiarism could be seen in Paper 10 (Class A).

Paper 10 (Class A)

All research writing begins with one of three broad kinds of topics: Assigned Topics that are selected by an instructor and presented to you, often as a list of actual writing subjects to choose from; Field-of-Study Topics that you choose, so long as they are related to the course for which the paper is assigned; and Free-Choice Topics that give you free rein to investigate any area you choose (Roth, 1986).

Before knowing the original source, it seemed that the student who wrote Paper 10 (Class A) had produced a good and acceptable paraphrase by providing the information of the original source with in-text citation. The student mentioned the author and the published year (Roth, 1986), and then put them together in parentheses (brackets) at the end of the 
paraphrase. When the lecturer read this paraphrase, s/he might assume that the words were the student's own. It was because of the absence of quotation marks which could falsely indicate that the language and wording in this passage belong to the student. However, after being compared with the original source, what happened actually was that the student did not paraphrase at all, but s/he merely copied the author's material verbatim.

Original Text

All research writing begins with one of three broad kinds of topics: Assigned Topics that are selected by an instructor and presented to you, often as a list of actual writing subjects to choose from; Field-of-Study Topics that you choose, so long as they are related to the course for which the paper is assigned; and Free-Choice Topics that give you free rein to investigate any area you choose. (In this book, the word topic is used to indicate a broad range or general field of interest, while subject refers to that part of a topic

Taken from:

The Research Paper: Process, Form, and Content By Audrey J. Roth. 1986. California: Wadsworth Publishing Company. Page 15

This practice was clearly unacceptable in academic writing. Every time the students use the exact material from the original author, they must always remember that providing reference at the beginning or at the end of borrowed material is not adequate in academic writing. Therefore, it could be summed up that the paraphrase in Paper 10 (class A) was classified as word-for-word plagiarism for the lack of quotation marks.

\section{b. Example of Forgetting to Document}

Based on the research findings, it was found that the second rank of type of problem frequently faced by Original Text

The definition of Young Learners is children between the ages of about 5 years old to 12 years old (Rixon, 1999), while according to Lynne Cameron; young learners are those under 14 years old. Moreover, the definition of young learners is mainly based on the years spent in the primary or elementary stages of formal education before the transition to secondary school.

Taken from:

"Teaching English to Young Learners through Songs." Yuliana

Volume 5, Number 1, June 2003: 62- 66.

Jurusan Sastra Inggris, Fakultas Sastra, Universitas Kristen Petra http://puslit2.petra.ac.id/ejournal/index.php/ing/article/viewFile/15498/15490 


\section{Paper 14 (Class A)}

According to Rixon (1999) as cited in Yuliana's journal "Teaching English to Young Learners Through Song" (2003), the definition of Young Learners is children between the ages of about 5 years old to 12 years old, while according to Lynne Cameron; young learners are those under 14 years old. Moreover, the definition of young learners is mainly based on the years spent in the primary or elementary stages of formal education before the transition to secondary school.

The student who wrote the passage above produced unacceptable paraphrase for two reasons. First, $\mathrm{s} /$ he used the exact wording from the author without putting quotation marks (word-for-word plagiarism). Second, s/he failed to document the source properly for not mentioning the source in the reference list. Actually the student had mentioned the information of the source within the text. By mentioning the source of the information in the text (in-text citation), the readers were able to know that the information was actually taken from Rixon (1999) as cited in Yuliana in her journal entitled "Teaching English to Young Learners through Song" (2003). However, for those who were interested in reading the complete information would find it difficult to track the sources because there was no information about the source in the reference list.

\section{References}

Taylor, Linda. 1994. Teaching and Learning Vocabulary.

Philips, Sarah. 1993. Young Learners. New York: Oxford University Press.

Saricoban, Arif \& Esen Metin. 2000. Songs, Verse, and Games for Teaching Grammar. Retrieved on March 24, 2011 from http://iteslj.org/Techniques/Saricoban-Songs.html

From the reference list above, it could be seen that the student did not mention the complete information about Yuliana's journal entitled "Teaching English to Young Learners through Song" (2003). In fact, the student should always remember that every source mentioned in his/her writing must be also put in the reference list.

\section{c. Example of a Patchwork Paraphrase}

Paper 11 (Class F)

Internet is a network which contains much information. It is connected together by telephone

$\underline{\text { lines }}$ and also connected to the computer. It has been known as the modern and fast development in communication tools. Internet provides much information through various applications in it. (Teeler \& Gray, 2000: 1)
The researchers would like to discuss one of the examples of a patchwork paraphrase taken from Paper 11 (Class F). The student actually had provided clear in-text citation within his/her paraphrase (the author, the year, and the page number to locate the source). After being compared with the original text, unfortunately the bold phrases which were underlined indicated that the student still retained the author's language. 


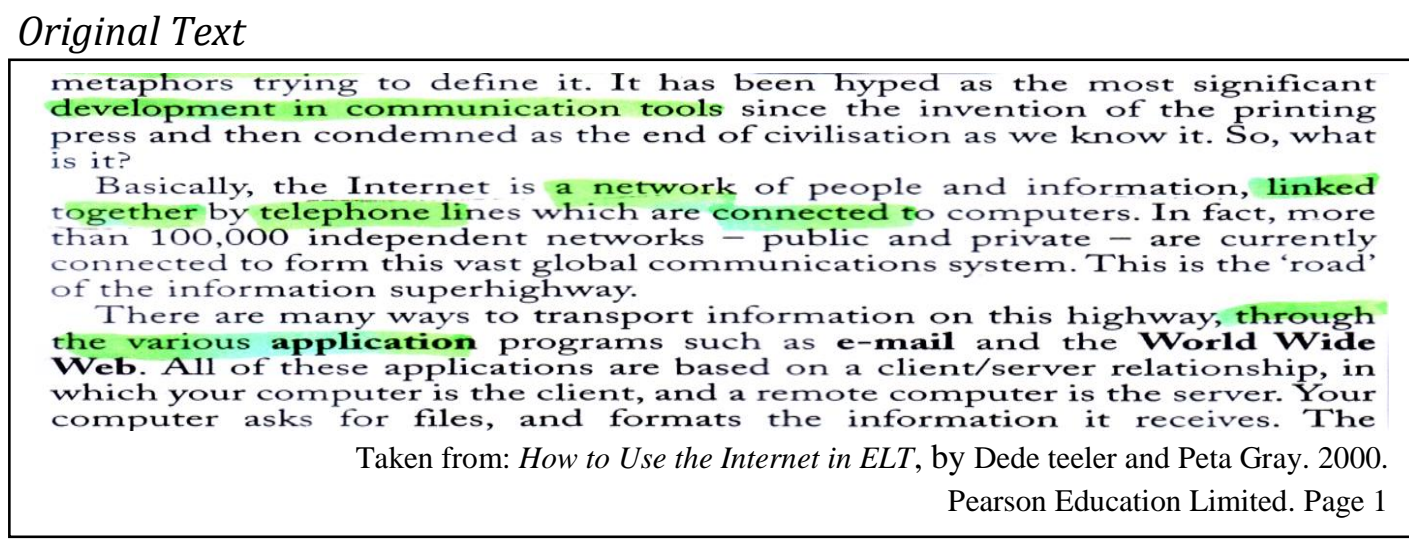

In his/her paraphrase, the student cut and pasted certain phrases from the original, like "together by telephone lines", "connected to the computer", "development in communication tools", and "through various applications." As a result, the student's attempt to paraphrase properly was unsuccessful for retaining too much of the original wording. The student actually could avoid this problem by enclosing the borrowed phrases within quotation marks. However, s/he ought to be careful because too many direct quotations could distract the readers. In addition, as a result of cutting and pasting from the original material, the student had also left out some important information, for example the student did not mention the reason why internet became the most important communication tool, the information about public and private independent networks, and Original Text the ways to transfer the information. To sum up, there were three problems found in this paraphrase. They were a patchwork paraphrase with in-text citation, including too much of the original, and leaving out important information.

\section{d. Example of Including Too Much of the Original}

Similar to a patchwork paraphrase, close paraphrases which were included in including too much of the original also occurred 17 times $(10 \%)$. A paraphrase could be included in this type of problem when it closely followed either the wording or the sentence structure of the original text. Close paraphrasing is unacceptable in academic writing. Therefore, if the students want to retain certain words from the original source, they should enclose the words in quotation marks. To give a more detailed description, the researchers provided one of the examples of this problem.

The interview is one of the most widely used methods for obtaining qualitative data. Interviews are used to gather data on subjects' opinions, beliefs, and feelings about the situation in their own words. Interviews provide information that cannot be obtained through observation, or they can be used to verify the observation. The qualitative interview is 


\section{Paper 13 (Class D)}

Ary et al. (2002: 434) state that interview is one of the instruments that most qualitative researchers use due to its advantage. By doing interviews, the researcher is able to obtain people's opinions, beliefs, and feelings about particular topic or situation in their own words.

The paraphrase above clearly indicated the information about the source, like the author, the date, and the page number (Ary et al., 2002, $p$. 434). The source had also been well documented in the reference list. Although the paraphrase was clearly documented, this paraphrase was still unacceptable. The student who wrote the paraphrase above had attempted to restate the original passage. Unfortunately, from the bold phrases which were underlined, it could be seen that the student still maintained the author's wording. Other examples of identified problems in paraphrasing could be found in Appendix 1.

\section{The Students' Reasons for Producing Unacceptable Paraphrases}

The research findings indicated that there were nine students' reasons for producing unacceptable paraphrases. The first reason was the students' own carelessness for both skipping a careful note taking step and paraphrasing directly from the source. Although note taking is recommended by many experts (Gibaldi, 2003; Hedstrom, 2006; Hubbuch, 1992; Spatt, 1999) to track the sources used in writing, none of the respondents applied a careful note taking in their research process. Moreover, some of the respondents admitted that they directly looked at the books while paraphrasing. This way of paraphrasing was so risky because the students could be tempted to copy the author's wording. Second, why the students produced unacceptable paraphrases was because they did not provide enough time to practice paraphrasing which resulted in the students' inability in paraphrasing. Third, the interview results also indicated that the students were still confused in differentiating between quotation and paraphrase in the real practice. As a result, a lot of the students produced paraphrases which were too close to the original sources. The fourth students' reason deals with a lack of vocabulary. Some respondents admitted that they had difficulties in finding the alternative words to replace the author's words. Having limited vocabulary was risky because the students would tend to retain the author's words. Fifth, the findings from the interviews further indicated the students' inability to manage their time well. In other words, being procrastinated was one of the students' reasons for producing unacceptable paraphrases. The sixth reason proposed by the students was that the lecturers did not pay attention to the paraphrases in the students' papers so that the students considered it was all right for them to paraphrase sources carelessly. Some respondents even frankly admitted that they ignored the correct form of paraphrase since their lecturers did not check their 
paraphrases. Afterwards, the seventh reason proposed by the students was insufficient feedback from the lecturers. Therefore, they were unable to produce a proper paraphrase. The next students' reason for producing unacceptable paraphrases was an inappropriate procedure applied by the students in the process of writing paraphrases. Based on the interview results, there was one respondent who admitted that $\mathrm{s} /$ he applied translation process in paraphrasing. However, applying translation processs in paraphrasing could be perilous for the students since they could possibly leave out the detailed information from the passage within the translation process. Subsequently, the last reason given by the respondents deals with the students' bad behavior. Some respondents stated that one of the factors which made the students copied and pasted from various sources to accomplish their research papers was the students' own laziness.

\section{CONCLUSIONS}

First, the research findings indicated that most ELESP students who were taking Research Paper Writing class in the academic year 2010/2011 encountered difficulties in writing acceptable paraphrases. It could be seen from the very high number of the students who produced unacceptable paraphrases. Moreover, based on the students' unacceptable paraphrases, the researchers found 170 problems which were categorized into (1) paraphrase pitfalls involving: forgetting to document occurred 19 times $(11.18 \%)$, including too much of the original occurred 17 times $(10 \%)$, misreading the original occurred 9 times (5.3\%), leaving out important information occurred 6 times (3.53\%), adding opinion occurred 5 times (2.9\%), expanding or narrowing the meaning occurred twice $\quad(1.18 \%)$, substituting inappropriate synonyms occurred once $(0.58 \%)$ and (2) plagiarism in paraphrasing involving: word-forword plagiarism occurred 94 times (55.3\%) and a patchwork paraphrase occurred 17 times (10\%). Second, the research findings also indicated that there were nine students' reasons for producing unacceptable paraphrases, involving: (1) carelessness in the research process, (2) a lack of practice, (3) confusion about the procedure, (4) a lack of vocabulary, (5) procrastination, (6) a lack of attention from the teachers, (7) insufficient feedback, (8) inaccurate procedure in paraphrasing, and (9) laziness.

Based on the research findings, firstly, the researchers would like to encourage ELESP students to avoid inadvertent plagiarism by using a note taking during the research process to gain precise records of their sources. The researchers also emphasize the importance of acknowledging internet sources as necessary as printed sources. Secondly, ELESP lecturers are recommended to introduce the students the risks of plagiarism from the beginning writing courses, model how to write a paraphrase and provide exercises in which the students can practice their paraphrasing skill. Dealing with plagiarism practice, the lecturers are also encouraged to provide guidelines on how to credit sources properly. Importantly, the lecturers are also recommended to use search engines to be able to detect plagiarism and be strict with plagiarism. 


\section{REFERENCES}

Division of Teaching \& Learning Services of Central Queensland University. (2007). Harvard (author-date) Referencing Guide. Retrieved on May 4, 2011, from http://www.intec.edu.do/pdf/ HARVARD/harvardguide \%5B2\%5D.pdf

Gibaldi, J. (2003). MLA Handbook for Writers of Research Paper. New York: The Modern Language Association of America.

Gilmore, B. (2008). Plagiarism: Why it Happens, How to Prevent it. Portsmouth: Heinemann.

Hong Xu, S. (2010). Teaching English Language Learners: Literacy Strategies and Resources for K-6 [Electronic version]. New York: The Guilford Press.

Hubbuch, S. M. (1992). Writing Research Papers across the Curriculum (3 ${ }^{\text {rd }}$ ed.). Fort Worth: Harcourt Brace Jovanovich College Publishers.

Kennedy, M. L., \& Smith, H. M. (1986). Academic Writing: Working with Sources across the Curriculum [Electronic version]. New Jersey: PrenticeHall.

Latrobe University. (2010). Referencing and Paraphrasing (How to Avoid Plagiarism). Retrieved on May 4, 2011, from http://www.lib.latrobe.edu.au /help/STE-Referencing-Guide2010.pdf
McNamara, D. S. (2007). Reading Comprehension Strategies: Theories, Interventions, and Technologies [Electronic version]. New Jersey: Lawrence Erlbaum Associates, Inc.

MIT Academic Integrity. (2010). Avoiding Plagiarism: Paraphrasing. Retrieved on March 25, 2011, from http://web.mit.edu/academici ntegrity/ plagiarism/paraphrasing.html

Prabandari, C. S. (1997). Students' Problems in Writing Quotations: Research on Students Writing VIII Final Assignments of the English Language Education Study Programme. Unpublished Thesis. Yogyakarta: Sanata Dharma University.

Roth, A. J. (1986). The Research Paper: Process, Form, \& Content. California: Wadsworth, Inc.

Spatt, B. (1999). Writing from Sources (5 th $^{\text {ed. }) . ~ B o s t o n: ~}$ Bedford.

The Higher Education Academy. (2011). Addressing Plagiarism. Retrieved on August 20, 2011, from http://www. heacademy.ac.uk/resources/d etail/internationalisation/ISL_ Plagiarism

The Writing Center of University of Wisconsin-Madison. (2003). Acknowledging, Paraphrasing, and Quoting Sources. Retrieved on May 4, 2011, from http://writing.wisc.edu/Handb 
ook/Acknowledging_Sources. pdf
Trzeciak, K., \& Mackay, S. E. (1998).

Study Skills for Academic Writing.

Hertfordshire: Prentice Hall

Europe.

\section{Appendix 1}

Table 1: Samples of Analysis Result of Students' Unacceptable Paraphrases

\begin{tabular}{|c|c|c|c|}
\hline No. & Paraphrase & Original Source & Explanation \\
\hline 1. & $\begin{array}{l}\text { Paper } 11 \text { (Class } \\
\text { A) } \\
\text { Harmer (2001) } \\
\text { also explained } \\
\text { that listening is } \\
\text { an important } \\
\text { skill because it } \\
\text { provides the } \\
\text { great } \\
\text { opportunity } \\
\text { to hear voices } \\
\text { from native } \\
\text { speakers, and } \\
\text { it also enables } \\
\text { students to } \\
\text { improve their } \\
\text { own } \\
\text { pronunciatio } \\
\text { n as a result } \\
\text { of the spoken } \\
\text { English they } \\
\text { absorb from } \\
\text { the listening } \\
\text { material } \\
\text { (p.228) }\end{array}$ & $\begin{array}{l}\text { Students can improve their listening skills - and gain valuable language input- } \\
\text { through a combination of extensive and intensive listening material and procedures. } \\
\text { Listening of both kinds is sespecially important since it provides the perfect } \\
\text { opportunity to hear voices other than the teacher's, enables students to acquire good } \\
\text { speaking habits a a result of the spoken English they absorb, and helps to improve } \\
\text { their own pronunciation. } \\
\text { Taken from: The Practice of Language Teaching } \\
\text { By Jeremy Harmer. 2001. Pearson education } \\
\text { Limited: Essex }\end{array}$ & $\begin{array}{l}\text { Types of problem: } \\
\text { - A patchwork } \\
\text { paraphrase } \\
\text { Too much of the } \\
\text { original (wording) } \\
\quad \text { Narrowing the } \\
\text { meaning } \\
\text { That this paraphrase was a } \\
\text { patchwork paraphrase could } \\
\text { be noticed from the parts } \\
\text { which were similar to the } \\
\text { original text. The student had } \\
\text { also included too much of the } \\
\text { original wording as the result } \\
\text { of cutting and pasting words } \\
\text { from the original text. } \\
\text { Besides, in the paraphrase, } \\
\text { the student had narrowed the } \\
\text { meaning conveyed in the } \\
\text { original text. In the original } \\
\text { text, it could be identified that } \\
\text { the author actually discussed } \\
\text { the way to increase listening } \\
\text { skill by using "a combination } \\
\text { of extensive and intensive } \\
\text { listening material and } \\
\text { procedures." On the contrary, } \\
\text { in the paraphrase, the student } \\
\text { changed the subject of the } \\
\text { discussion into "listening skill" } \\
\text { which was irrelevant with the } \\
\text { source. Instead of showing } \\
\text { that certain listening } \\
\text { materials and procedures } \\
\text { could improve listening skill, } \\
\text { the student narrowed this } \\
\text { information } \\
\text { misrepresented the original } \\
\text { meaning. This practice was } \\
\text { clearly unacceptable in } \\
\text { paraphrasing. }\end{array}$ \\
\hline
\end{tabular}




\begin{tabular}{|c|c|c|c|}
\hline No. & Paraphrase & Original Source & Explanation \\
\hline 2. & $\begin{array}{l}\text { Paper } 5 \text { (Class } \\
\text { A) } \\
\text { The main } \\
\text { purpose in } \\
\text { listening class } \\
\text { is to gain } \\
\text { comprehensio } \\
\mathrm{n} \text { and in depth } \\
\text { understanding } \\
\text { about the } \\
\text { information } \\
\text { that has been } \\
\text { listened to by } \\
\text { the students } \\
\text { (Nunan, 1991: } \\
\text { 23-24) }\end{array}$ & 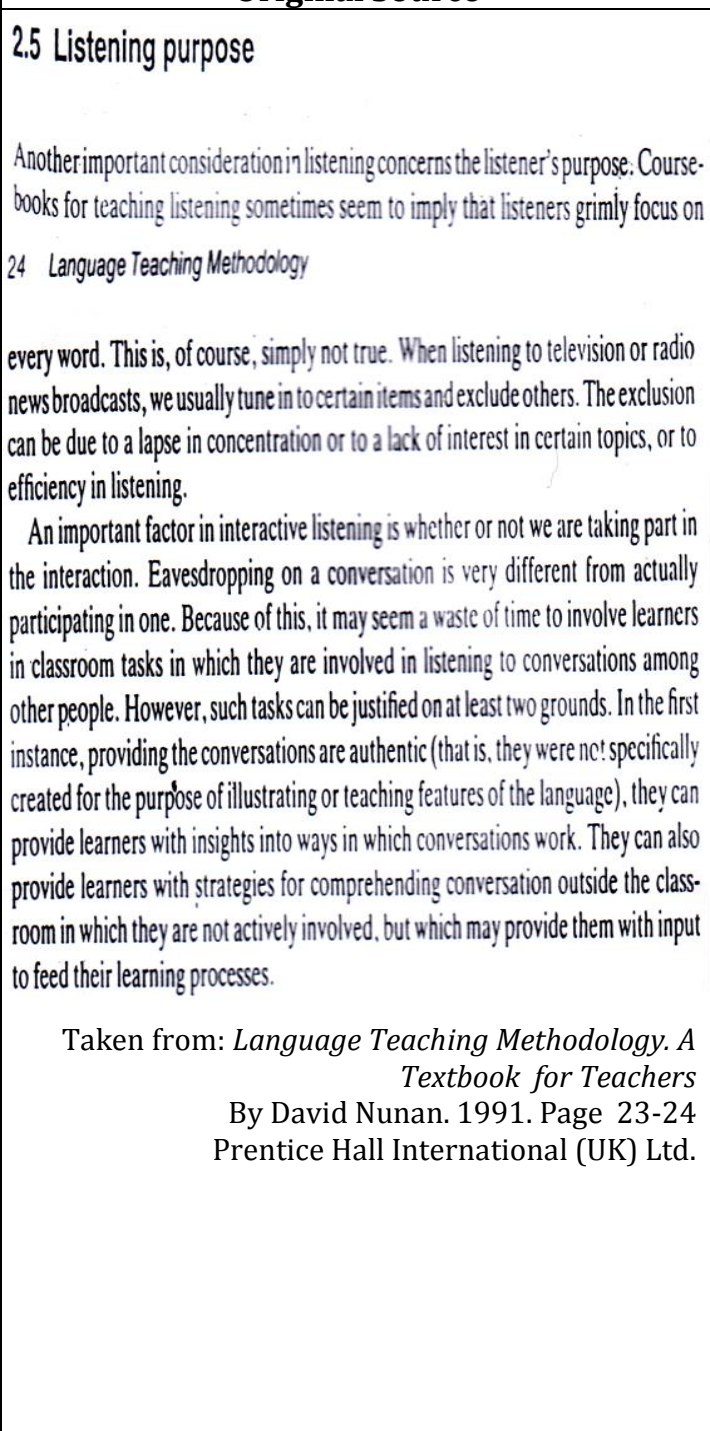 & $\begin{array}{l}\text { Type of problem: } \\
\text { - Misreading } \\
\text { original } \\
\text { After being compared with the } \\
\text { original source, the } \\
\text { information conveyed in the } \\
\text { paraphrase did not match } \\
\text { with the original passage. In } \\
\text { the original text, there was no } \\
\text { information about the main } \\
\text { purpose of listening class as } \\
\text { stated by the student. On the } \\
\text { other hand, the author } \\
\text { actually discussed about the } \\
\text { listener's purpose as one of } \\
\text { the significant elements which } \\
\text { should be considered in } \\
\text { listening. The author also } \\
\text { further explained about the } \\
\text { advantages of having } \\
\text { authentic materials in } \\
\text { conversation as a part of } \\
\text { interactive listening. } \\
\text { Therefore, it was clear that the } \\
\text { student had misunderstood } \\
\text { the meaning conveyed in the } \\
\text { original text. In fact, in writing } \\
\text { paraphrase, the student was } \\
\text { not allowed to guess the } \\
\text { meaning of the original } \\
\text { material because } \\
\text { paraphrasing should be a } \\
\text { clear and arcurate } \\
\text { restatement of the source. }\end{array}$ \\
\hline 3. & $\begin{array}{l}\text { Paper } 3 \text { (Class } \\
\text { F) } \\
\text { According to } \\
\text { Gebhard, G. } \\
\text { Jerry } \\
\text { (1998.p.176), } \\
\text { role play is } \\
\text { activity where } \\
\text { the students } \\
\text { are expected } \\
\text { to act based } \\
\text { on the } \\
\text { situation and } \\
\text { role given. In } \\
\text { this activity, } \\
\text { students will } \\
\text { be asked to be } \\
\text { a certain } \\
\text { character, and } \\
\text { must speak } \\
\text { like the way } \\
\text { the characters } \\
\text { are. So, this }\end{array}$ & $\begin{array}{l}\text { Dialogue Writing, Skits, Role Plays, and Improvisations } \\
\text { Some teachers have students write their own dialogues, and stu- } \\
\text { dents generally like this because they can consider their own inter- } \\
\text { active needs. When students act put their dialogues, they become } \\
\text { skits, the idea being for students to practice and then give a perfor- } \\
\text { mance in front of the class. Role play activities are similar to skits in } \\
\text { that students are expected to act. However, unlike skits, students } \\
\text { are not provided with lines but are given a situation and roles to } \\
\text { play. In chapter five I give an example of a role play in a restaurant. } \\
\text { Taken from } \\
\text { Teaching English as a Foreign or Second Language. } \\
\text { A Teacher Self-development and Methodology } \\
\text { Guide. p.176 } \\
\text { By Jerry G. Gebhard. } 1998 \\
\text { The University of Michigan Press }\end{array}$ & $\begin{array}{l}\text { Types of problem: } \\
\text { - Leaving out important } \\
\text { information } \\
\text { - } \text { patchwork } \\
\text { paraphrase } \\
\text { The waraphrase } \\
\text { unacceptable for two reasons. } \\
\text { First, from the bold phrases } \\
\text { which were underlined, it } \\
\text { could be noticed that the } \\
\text { student still used some exact } \\
\text { words from the author which } \\
\text { resulted in a patchwork } \\
\text { paraphrase. Second, the } \\
\text { student had left out important } \\
\text { information. In the original } \\
\text { text, the author actually } \\
\text { described role play activity by } \\
\text { comparing it with skit (a } \\
\text { short play). The author } \\
\text { explained the activities in role } \\
\text { play by showing the similarity } \\
\text { and the difference between }\end{array}$ \\
\hline
\end{tabular}




\begin{tabular}{|c|c|c|c|}
\hline No. & Paraphrase & Original Source & Explanation \\
\hline & $\begin{array}{l}\text { activity } \\
\text { demands } \\
\text { students to } \\
\text { participate. }\end{array}$ & & $\begin{array}{l}\text { skit and role play. However, in } \\
\text { his/her paraphrase, the } \\
\text { student omitted this } \\
\text { information. }\end{array}$ \\
\hline 4. & $\begin{array}{l}\text { Paper } 6 \text { (Class } \\
\text { F) } \\
\text { Speaking skill } \\
\text { is one of skills } \\
\text { which is } \\
\text { required in } \\
\text { learning a } \\
\text { language. } \\
\text { Mastering } \\
\text { speaking is the } \\
\text { most important } \\
\text { skill } \\
\text { students for } \\
\text { especially for } \\
\text { those who } \\
\text { learn English } \\
\text { as their second } \\
\text { language or } \\
\text { foreign } \\
\text { language } \\
\text { (Richards, } \\
\text { Jack. C) }\end{array}$ & $\begin{array}{l}\text { The mastery of speaking skills in English is a } \\
\text { priority for many second or foreign language } \\
\text { learners. } \\
\text { Taken from: } \\
\text { "Developing Classroom Speaking Activities; } \\
\text { From Theory to Practice" } \\
\text { By Jack C. Richards } \\
\text { http://www.professorjackrichards.com/pdfs } \\
\text { /developing-classroom-speaking- } \\
\text { activities.pdf }\end{array}$ & 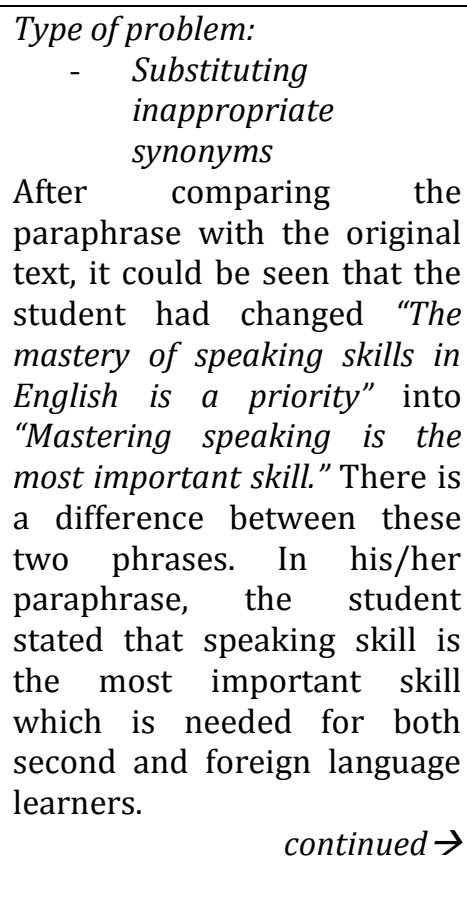 \\
\hline & & & $\begin{array}{l}\text { On the other hand, in the } \\
\text { original text, the author } \\
\text { argued that mastery speaking } \\
\text { skill is a priority. In other } \\
\text { words, the three other skills, } \\
\text { like reading, listening, and } \\
\text { writing, are also important, } \\
\text { but speaking skill should be } \\
\text { preferred by the students } \\
\text { who study English as their } \\
\text { foreign or second language. } \\
\text { Although the student only } \\
\text { substituted one inappropriate } \\
\text { synonym, the meaning would } \\
\text { be so different that it could } \\
\text { lead into another meaning of } \\
\text { the whole sentence. }\end{array}$ \\
\hline
\end{tabular}




\begin{tabular}{|c|c|c|c|}
\hline No. & Paraphrase & Original Source & Explanation \\
\hline 5. & 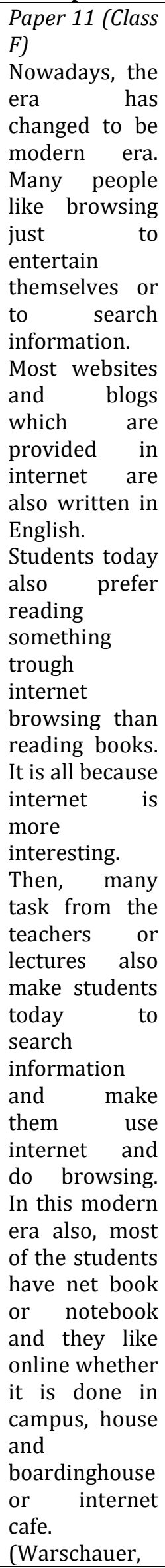 & $\begin{array}{l}\text { anguage. Writing. Print. These are the three great revolutionary develop- } \\
\text { ments in communication and cognition, each one ushering in a new level } \\
\text { of human civilization. And now we are in the midst of another revolution } \\
\text { in human communication, based on the development and spread of computers } \\
\text { and the Internet. } \\
\text { Just as the development of the printing press } 500 \text { years ago dramatically } \\
\text { expanded the information available to individuals and society, the development } \\
\text { of the Internet is doing so today. With a single computer and a telephone line, a } \\
\text { young child in a rural village can access more information today than was } \\
\text { available by any means to the greatest scientists of the world a century ago. } \\
\text { The Internet is reshaping nearly all aspects of society. On-line advertising, } \\
\text { marketing, and sales are growing at exponential rates and shaking up the world's } \\
\text { financial markets. Many schools in the developed countries are now wired for the } \\
\text { Internet, inspiring grassroots efforts to reform education in order to take better } \\
\text { advantage of information technology. A majority of university students and } \\
\text { professors in the industrialized countries use the Internet to share ideas, conduct } \\
\text { research, and collaborate in the production of knowledge. Music, media, politics, } \\
\text { entertainment-name the field, and it is being transformed by the Internet. } \\
\text { Taken from: Internet for English Teaching by Mark } \\
\text { Warschauer, Heidi Shetzer, and Christine Meloni. } \\
2000 \text {. Page } 1\end{array}$ & $\begin{array}{l}\text { Type of problem: } \\
\text { - Adding opinion } \\
\text { Although the researcher did } \\
\text { not find any similar wording, } \\
\text { the researcher found that the } \\
\text { information in the student's } \\
\text { paraphrase did not match } \\
\text { with the original text when } \\
\text { they were read and compared } \\
\text { carefully. In his/her } \\
\text { paraphrase, the student } \\
\text { discussed about the use of } \\
\text { internet in the modern era, } \\
\text { especially for the college } \\
\text { students. Meanwhile, in the } \\
\text { original text, the authors } \\
\text { actually talked about the rapid } \\
\text { development of internet and } \\
\text { the use of it in certain aspects } \\
\text { of society, for instance } \\
\text { financial markets, school and } \\
\text { other certain fields, like music, } \\
\text { media, politics, } \\
\text { entertainment. Therefore, it } \\
\text { could be noticed that the } \\
\text { student had misread the } \\
\text { original text. Afterwards, } \\
\text { instead of presenting an } \\
\text { accurate information } \\
\text { conveyed in the original text, } \\
\text { the student had added his/her } \\
\text { own opinion to the } \\
\text { paraphrase. }\end{array}$ \\
\hline
\end{tabular}




\begin{tabular}{|l|l|l|l|}
\hline No. & Paraphrase & \multicolumn{1}{|c|}{ Original Source } & Explanation \\
\hline & Shetzer \& & & \\
& Meloni & & \\
& $2000: 1)$ & & \\
\hline
\end{tabular}

\section{Appendix 2}

\section{The Interview Guide for the Students}

1. Seberapa sering kamu menggunakan parafrase di dalam tugas menulis di kelas Research Paper Writing? ( How often do you use paraphrases in your writing in Research Paper Writing class?)

2. Darimanakah kamu mendapat informasi tentang cara memparafrase? (Where do you get information about how to paraphrase?)

3. Bisakah kamu jelaskan bagaimana caramu memparafrase sumbersumber yang kamu gunakan di tulisanmu? (How do you paraphrase your sources in your writing?)

4. Menurutmu, bagaimana ciri-ciri parafrase yang benar dan bisa diterima? (What are the characteristics of correct and acceptable paraphrase in your opinion?)

5. Apakah kamu sudah memparafrase sumber-sumber referensi dalam tulisanmu dengan benar? Mengapa? (Have you paraphrased your sources correctly/acceptably? Why?)

6. Bagaimana pendapatmu tentang parafrase yang terlalu mirip dengan sumber aslinya? (What do you think about paraphrases which are too close to the original source?)

7. Apa yang kamu ketahui tentang plagiarisme? (What do you know about plagiarism?)

8. Menurutmu hal-hal apa saja yang menyebabkan terjadinya plagiarisme terutama di kelas RPW? (Why do the students do plagiarism, especially in Research Paper Writing class?)

9. Adakah saran-saran yang bisa kamu berikan agar plagiarisme bisa dikurangi terutama di kelas RPW? (What suggestions do you have to minimize plagiarism cases in Research Paper Writing class?) 